\title{
Yield and Economic Effectiveness of Soybean Grown Under Different Cropping Systems
}

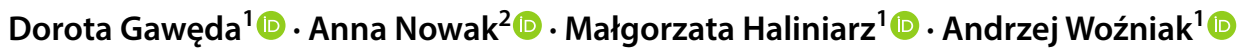

Received: 5 November 2019 / Accepted: 28 February 2020 / Published online: 12 March 2020

(c) The Author(s) 2020

\begin{abstract}
An increase in the area under soybean and other legume crops in Europe is one of the assumptions of the European Soya Declaration. A study was undertaken to evaluate the influence of cropping system and tillage system on yield, some quality characteristics of soybean seeds and economic evaluation. Therefore, this paper is of interdisciplinary nature. On average over a four-year study period, the soybean seed yield was significantly higher in monoculture compared to the yield obtained in crop rotation. A decreasing trend in yield of monocultured soybean was only observed in the 4th year of the experiment. Seeds grown in monoculture were characterized by a significantly higher percentage protein content and a lower fat content compared to obtained in crop rotation. Plough tillage affected more beneficially soybean yield. Under no-tillage conditions, soybean seeds were shown to have a higher percentage protein content and a lower fat content. The average income per ha of soybean grown under plough tillage system was higher by EUR 64.6 than that under no-tillage. In comparing production profitability depending on the cropping system, it can be noted that it was more beneficial to grow soybean in monoculture. In monoculture, both plough tillage and no-tillage generated a higher income per ha than in the case of soybean grown in crop rotation.
\end{abstract}

Keywords Glycine max $\cdot$ Productivity $\cdot$ Economic evaluation $\cdot$ Crop systems $\cdot$ Tillage systems

\section{Introduction}

An increase in the area under soybean and other legume crops in Europe, among others for animal feed purposes, is one of the assumptions of the European Soya Declaration signed by 13 Member States in Brussels on 17 July 2017 at a meeting of the Council of Ministers of Agriculture of the European Union. Since the time of the CAP reform in 2013, the area under soybean in the EU has doubled, reaching almost million hectares. In 2018 the EU's soybean production was 2.93 million tonnes. The main soybean producers are Italy, France, and Romania (European Commission 2018). In Poland soybean seed production still remains at a low level, but an increased interest in growing this legume crop has been observed in recent years. This results,

Małgorzata Haliniarz

malgorzata.haliniarz@up.lublin.pl

1 Department of Herbology and Plant Cultivation Techniques, University of Life Sciences in Lublin, Lublin, Poland

2 Department of Economics and Agribusiness, University of Life Sciences in Lublin, Lublin, Poland among others, from breeding new cultivars well-adapted to our climatic conditions and soybean's lower susceptibility to lodging compared to other legume crops. The high nutritional value of soybean seeds, which contain about $40 \%$ of protein with a good amino acid composition, $20 \%$ of fat with a high content of essential unsaturated fatty acids, and other valuable components, makes a good argument for the cultivation of soybean (Zeller 1999; Rogalska-Niedźwiedź 2000; Boros 2002; Abbasi Surki et al. 2010; Nowak 2011). Due to consumers' large interest in healthy food, soybean is grown more and more frequently under the organic system, in which it produces satisfactory yields (Cox et al. 2018; Vincent-Caboud et al. 2019).

Climatic conditions, primarily temperature and rainfall, are factors that limit soybean yields (Vollmann et al. 2000; Ohnishi et al. 2010). The adaptation of crop agronomy to climate change is of special significance for legumes which exhibit low yield stability (Vadez et al. 2011; Reckling et al. 2018). In areas with low rainfall levels, it is very important to prepare the soil in a way that will ensure retention of the highest possible amount of rainwater. Agronomic practices involving the replacement of the plough with implements 
that do not turn the soil over offer this possibility to agricultural producers. This is confirmed by a study described in an article written by Pittelkow et al. (2015) which proves that no-tillage (NT) performs best in a dry climate and crop yields are often equal to or higher than those obtained under conventional tillage conditions. Existing research reveals that NT beneficially affects the quality of soil by improving its structure and increasing biological activity, soil water retention capacity, water infiltration, and water consumption efficiency (Hobbs et al. 2008; Verhulst et al. 2010). Another aspect is also that NT can reduce production costs and increase profitability due to lower energy and labor consumption compared to the conventional system (Erenstein et al. 2012). Its economic benefits, coupled with lower soil erosion, are important aspects speaking for the use of no-till (Derpsch et al. 2010). Therefore, the decision to introduce no-till must be dictated by both economic and environmental considerations.

Numerous studies dealing with growing crops in crop rotation prove that it prevents soil depletion, the spread of diseases and pests, and hence enhances crop yields (Plourde et al. 2013; Kelley et al. 2003; Bellaloui et al. 2010). Symptoms of many diseases caused by fungi can be observed on soybean, but currently they are not economically important in Poland and usually do not require the use of chemical fungicides. Also, it is rarely necessary to apply direct pest control (Praczyk et al. 2012). The above considerations justify undertaking research regarding the response of this valuable leguminous plant to short-term monoculture cropping.

The study presented in this paper was undertaken due to a limited number of literature reports regarding the response of soybean to monoculture cropping and no-tillage. The study evaluated the influence of cropping system and tillage system on yield and some quality characteristics of soybean seeds. It also evaluated the economic effects of the investigated soybean production technologies under soil and climatic conditions of the Lublin Upland.

\section{Materials and Methods}

\section{Location of the Experiment and Soil and Climatic Conditions}

A field experiment was conducted at the Uhrusk Experimental Farm $\left(51^{\circ} 18^{\prime} 11^{\prime \prime} \mathrm{N}, 23^{\circ} 36^{\prime} 50^{\prime \prime} \mathrm{E}\right)$ over the period 2014-2017 on Rendzic Phaeozem (IUSS Working Group WRB 2015), with grain-size distribution of sandy loam. The soil showed alkaline $\mathrm{pH}$ (in $1 \mathrm{M} \mathrm{KCl}=7.7)(\mathrm{PN}-\mathrm{ISO}$ 10390:1997P). It was characterized by very high availability of phosphorus (229.8 $\mathrm{mg} \mathrm{P} \mathrm{kg}^{-1}$ soil) (PN-R-04023:1996P), high potassium availability (150.2 $\mathrm{mg} \mathrm{K} \mathrm{kg}^{-1}$ soil) (PNR-04022:1996/Az1:2002P), and very low magnesium

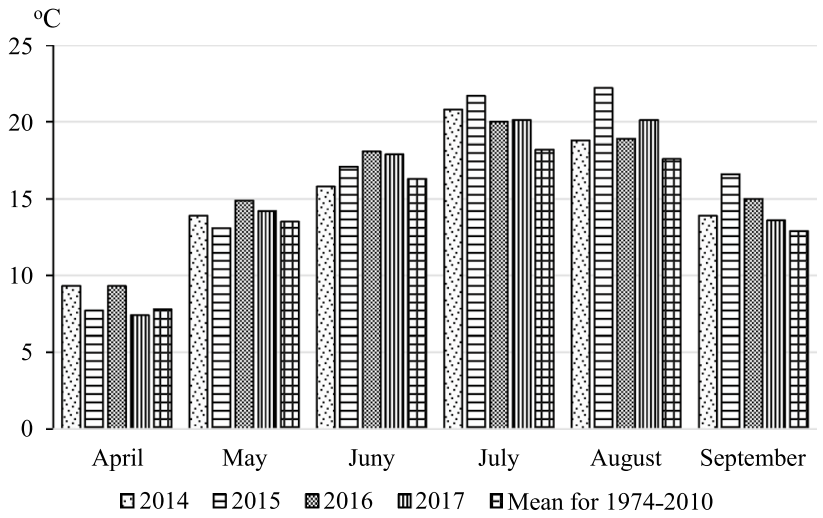

Fig. 1 Mean monthly air temperature $\left({ }^{\circ} \mathrm{C}\right)$ at the Bezek Meteorological Station in 2014-2017

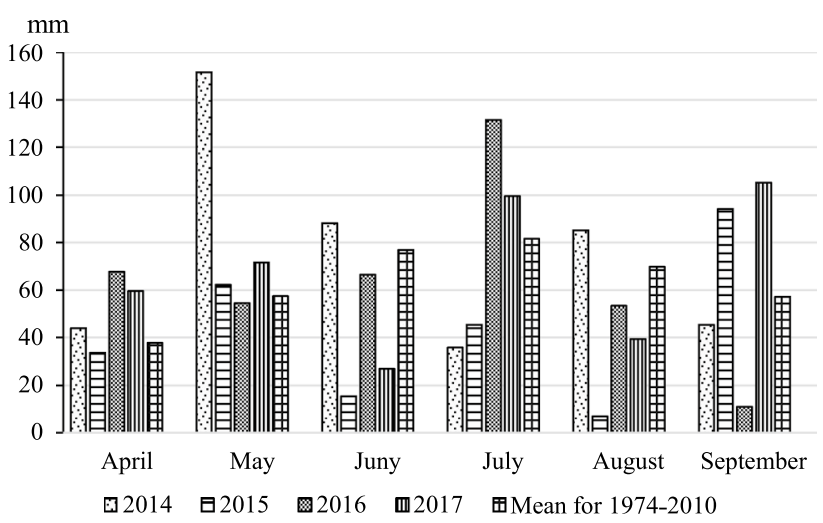

Fig. 2 Total rainfall and rainfall distribution $(\mathrm{mm})$ at the Bezek Meteorological Station in 2014-2017

availability (16 mg Mg kg-1 soil) (PN-R-04020:1994/ Az1:2004P). The humus content was at a level of $1.5 \%$ (KQ/ PB-34), whereas the content of fine particles $(<0.02 \mathrm{~mm})$ in the $0-30 \mathrm{~cm}$ layer was $20.7 \%$.

During the growing season of soybean, from April to September (IV-IX), the average air temperature in all study years was higher than the long-term average (Figs. 1 and 2). Throughout the duration of the experiment, favorable temperatures for soybean growth were recorded from July to September - during the generative growth period (Fig. 1). The years 2015 and 2017 proved to be unfavorable for soybean development and yield. In 2015 during the month of sowing and initial growth of soybean (May) when the thermal requirements of this crop are very high, a lower temperature was recorded than the long-term average. The second growing season of soybean (2015) was also characterized by lower rainfall relative to the other years of the experiment and the long-term average. In 2015 the highest rainfall deficits were observed in the months June-August, during the generative growth period, whereas in September excessive rainfall delayed 
the maturation of soybean and hindered its harvest. The year 2017 was unfavorable for soybean growth, particularly in terms of precipitation distribution. In June (flowering stage) a rainfall deficit was recorded, whereas in July (flowering/seed filling) and in September there was excessive rainfall. Abundant rainfall in September negatively affected even ripening of soybean and delayed its harvest. In the last year of the experiment (2017), a lower temperature than in the other years and compared to the long-term average was recorded in April; due to this, and also because of torrential rains, soybean was sown in the first 10 days of May.

\section{Experimental Design and Agronomic Practices}

The experiment was set up as a split-block design in three replicates. Soybean was grown in an area of $768 \mathrm{~m}^{2}$, while the single plot area was $32 \mathrm{~m}^{2}$. This research evaluated the response of soybean (cultivar 'Merlin') to two study factors:

CS Cropping system CR: soybean after the previous winter wheat crop (crop rotation: soybean — winter wheat-winter oilseed rape-winter wheat), CM: soybean monoculture cropping.

TS Tillage system CT: plough tillage (skimming + harrowing, harrowing, autumn ploughing; spring: harrowing, NPK application, cultivating with harrowing, seeding, harrowing), NT: no-tillage (stubble cultivator: grubber + cage roller instead of skimming and cultivating instead of autumn ploughing); in the spring, the same agronomic operations were carried out as under plough tillage system.

Mineral fertilization was applied in full before seeding at the following rates: $\mathrm{N}-30 \mathrm{~kg} \mathrm{ha}^{-1}, \mathrm{P}-40 \mathrm{~kg} \mathrm{ha}^{-1}$, $\mathrm{K}-80 \mathrm{~kg} \mathrm{ha}^{-1}$. Fertilizer rates were determined based on the nutritional requirements of the crop plant and soil nutrient availability.

Before seeding, soybean seeds were inoculated with Bradyrhizobium japonicum bacteria and the seed dressing Vitavax 200 FS (a.i. carboxin, thiuram) was applied at a rate of $400 \mathrm{ml} / 100 \mathrm{~kg}$ seed. In the years 2014 and 2016, soybean was sown in the last 10 days of April, whereas in 2015 and 2017 in the first 10 days of May, at a depth of $3 \mathrm{~cm}$, a plant density of 100 plants per $1 \mathrm{~m}^{2}$, and a row spacing of $20 \mathrm{~cm}$. Immediately after seeding, a mixture of the herbicides Afalon Dyspersyjny 450 SC (a.i. linuron)+Dual Gold 960 EC (a.i. S-metolachlor) was applied at a rate of $11+1.81 \mathrm{ha}^{-1}$.

Mechanical weed control treatments were the same under both tillage systems; they involved crop harrowing 3-4 days after seeding and double harrowing after emergence of soybean (at first trifoliate leaf stage- $\mathrm{BBCH}$-scale 12, and at third trifoliate leaf stage-BBCH-scale 13) (BBCH Working Group 2001).
In 2014 and 2016, soybean was harvested in the second 10 days of September, whereas in 2015 and 2017 in the third 10 days of September-at full maturity (BBCH-scale 89).

\section{Scope of Study and Statistical Analysis}

The crop and yield characteristics [thousand seed weight (TSW), plant height, first pod height, number of pods per plant, number of seeds per pod, number and weight of seeds per plant] were determined based on a sample consisting of 30 randomly selected plants from each plot. Plant density after emergence and before harvest was estimated in two rows along a length of $2.5 \mathrm{~m}$.

The seed yield was weighed separately for each plot and the obtained results were expressed on a per hectare basis.

The protein and fat content in soybean seeds was determined on an OmegAnalyzer G spectrophotometer.

The results regarding soybean yield as well as protein and fat content in soybean seeds collected over the period 2014-2017 were subjected to analysis of variance, whereas the significance of differences was estimated by Tukey's test at a level of significance of $p=0.05$. ANALWAR5.3.FR software was used for calculations. Moreover, to establish correlations and relationships between the selected characteristics (yield and its components), Pearson's linear correlation coefficient was determined, a linear regression analysis was performed, and the coefficient of determination $\left(\mathrm{R}^{2}\right)$ was derived. Statistica 13.1 software was used for the above-mentioned calculations.

To perform an economic evaluation of the investigated soybean production technologies, the following economic categories, consistent with the profit and loss account applicable in the European Farm Accountancy Data Network, were used: gross margin and operating income. According to the EU methodology, gross margin is the annual output per crop hectare less direct costs incurred to produce this output (Goraj and Mańko 2009). The direct costs of crop production include: the cost of seeds, fertilizers, plant protection products and growth regulators as well as specific costs, that is of direct relevance to a specific activity and improving the quality and value of the final product (Skarżyńska et al. 2016). In turn, operating income is the excess left after total cost items (direct and indirect costs) have been deducted from the value of output. Two income categories were calculated in this studyoperating income without direct payments and operating income with direct payments. The latter type of income was increased in relation to the former one by including in it direct payments, i.e. single area payment (SAP), greening payment, seed payment, and protein crop payment. 


\section{Results and Discussion}

\section{Yield and Protein and Fat content in Soybean Seeds}

Soybean is a plant very sensitive to environmental stresses, such as low and high temperature or drought. In particular, low temperatures are a factor that strongly determines the production of this crop (Vollmann et al. 2000; Ohnishi et al. 2010). The critical periods in terms of water requirements and thermal conditions occur from sowing to full emergence as well as during flowering and seed maturation stages (Bieniaszewski et al. 2000; Kołodziej and Pisulewska 2000; Thuzar et al. 2010). In the present study, the year 2016, which was characterized by high temperature during the growing season and moderate rainfall during seed maturation, proved to be the most favorable for soybean yield. The yield harvested in this year was significantly higher than in the other years of soybean cropping, especially compared to the yields obtained in the years 2015 and 2017 that were characterized by unfavorable weather conditions for soybean growth (Figs. 1 and 2, Table 1).

On average over the four-year study period, the soybean seed yield was significantly higher in monocultural stands compared to the yield obtained in crop rotation (by 5.0\%). The important fact is that a decreasing trend in monocultured soybean was only observed in the 4th year of the experiment (Table 1). Under crop rotation in the stand after winter wheat, thousand seed weight, number of pods per plant, number and weight of seeds per plant, and plant height were found to be significantly lower, whereas the density of soybean plants after emergence and before harvest was insignificantly higher. The pod height in soybean plants grown in crop rotation was lower, which resulted in a higher seed yield loss during harvest than in the case of
Table 1 Soybean seed yield depending on cropping system and tillage system throughout the study period $\left(\mathrm{t} \mathrm{ha}^{-1}\right)$
Table 2 Soybean crop and yield components on average for cropping system and tillage system (average for 2014-2017)

\begin{tabular}{|c|c|c|c|c|c|c|c|c|c|}
\hline \multirow[t]{2}{*}{ Year } & \multicolumn{3}{|c|}{ Crop rotation } & \multicolumn{3}{|c|}{ Monoculture } & \multicolumn{2}{|c|}{ Mean } & \multirow[t]{2}{*}{ Mean } \\
\hline & CT & NT & Mean & $\mathrm{CT}$ & NT & Mean & CT & NT & \\
\hline 2014 & 2.48 & 2.61 & 2.55 & 2.73 & 2.65 & 2.69 & 2.61 & 2.63 & 2.62 \\
\hline 2015 & 2.10 & 1.82 & 1.96 & 2.23 & 1.86 & 2.05 & 2.17 & 1.84 & 2.01 \\
\hline 2016 & 3.06 & 2.81 & 2.94 & 3.59 & 3.23 & 3.41 & 3.33 & 3.02 & 3.18 \\
\hline 2017 & 2.40 & 1.75 & 2.08 & 1.87 & 1.79 & 1.83 & 2.14 & 1.77 & 1.96 \\
\hline Mean & 2.51 & 2.25 & 2.38 & 2.61 & 2.38 & 2.50 & 2.56 & 2.32 & - \\
\hline $\mathrm{LSD}_{0.05}$ & \multicolumn{9}{|c|}{$\begin{array}{l}\text { Cropping system }-0.115 \text {, tillage system }-0.115 \text {, years }-0.217 \text {, cropping system } \times \text { till- } \\
\text { age system }-n s \text {, cropping system } \times \text { years }-0.367 \text {, tillage system } \times \text { years }-n s \text {, cropping } \\
\text { system } \times \text { tillage system } \times \text { years }-n s\end{array}$} \\
\hline
\end{tabular}

$n s$ not significant at $\mathrm{p} \leq 0.05, C T$ plough tillage, $N T$ no-tillage

\begin{tabular}{|c|c|c|c|c|c|}
\hline \multirow[t]{2}{*}{ Specification } & \multicolumn{2}{|c|}{ Cropping system } & \multicolumn{2}{|c|}{ Tillage system } & \multirow[t]{2}{*}{$\mathrm{LSD}_{0.05}$} \\
\hline & $\mathrm{CR}$ & $\mathrm{CM}$ & $\mathrm{CT}$ & NT & \\
\hline Plant density after emergence (plants $\mathrm{m}^{-2}$ ) & 63.2 & 60.7 & 64.0 & 60.0 & $\begin{array}{l}\mathrm{CS}-\mathrm{ns} \\
\mathrm{TS}-3.56\end{array}$ \\
\hline Plant density before harvest (plants $\mathrm{m}^{-2}$ ) & 56.3 & 54.6 & 58.1 & 52.9 & $\begin{array}{l}\mathrm{CS}-\mathrm{ns} \\
\mathrm{TS}-3.22\end{array}$ \\
\hline Plant height $(\mathrm{cm})$ & 45.6 & 56.2 & 49.8 & 52.0 & $\begin{array}{l}\text { CS-1.93 } \\
\text { TS-1.93 }\end{array}$ \\
\hline First pod height $(\mathrm{cm})$ & 6.7 & 7.4 & 6.5 & 7.6 & $\begin{array}{l}\text { CS-0.37 } \\
\text { TS }-0.37\end{array}$ \\
\hline Number of pods per plant (pcs) & 17.2 & 19.6 & 19.6 & 17.2 & $\begin{array}{l}\mathrm{CS}-0.55 \\
\mathrm{TS}-0.55\end{array}$ \\
\hline Number of seeds per plant (pcs) & 35.8 & 37.2 & 38.2 & 34.7 & $\begin{array}{l}\text { CS-0.87 } \\
\text { TS- } 0.87\end{array}$ \\
\hline Seed weight per plant $(\mathrm{g})$ & 4.56 & 4.92 & 4.90 & 4.59 & $\begin{array}{l}\text { CS }-0.127 \\
\text { TS }-0.127\end{array}$ \\
\hline TSW (g) & 124.6 & 129.4 & 127.8 & 126.2 & $\begin{array}{l}\text { CS-1.24 } \\
\text { TS-1.24 }\end{array}$ \\
\hline
\end{tabular}

ns not significant at $\mathrm{p} \leq 0.05, C S$ cropping system, $C R$ crop rotation, $C M$ monoculture, $T S$ tillage system, $C T$ plough tillage, $N T$ no-tillage, $T S W$ thousand seed weight 
soybean grown in monoculture (Table 2). Similarly to other legume crops, soybean is most frequently grown after cereals and can be a crop that interrupts monoculture cropping of cereals. According to Praczyk et al. (2012), soybean can be successfully grown after itself for a period of two years in areas where it is cultivated for the first time. There are few literature reports on soybean yield in soil and climatic conditions of Poland under long-term monoculture. The study results presented in this paper prove that in the conditions of our country monoculture cropping of soybean for a period of 3 years does not cause a decrease in yield of this valuable legume crop. In turn, a study by Bujak et al. (2004), in which soybean was grown after itself for a period of five years, showed that seed yield was more determined by weather conditions than by the duration of monoculture cultivation of this crop. The possibility of growing soybean in the same stand is largely associated with its resistance to diseases and pests. In the conditions of our country, agricultural pests do not currently pose a big threat to soybean (Praczyk et al. 2012). However, research on monoculture cropping of soybean conducted under different soil and climatic conditions reveals that this cropping system causes a decrease in yield quality and quantity compared to conventional cultivation in crop rotation (Kelley et al. 2003; Bellaloui et al. 2010). In a study by Santos et al. (2014), a lower seed yield and weight per plant was obtained in soybean monoculture than in three comparable crop rotations Plourde et al. (2013). argue that crop rotation brings measurable environmental effects expressed in reduced occurrence of diseases, pathogens, and invasive plant species. This promotes obtaining higher seed yields compared to those found in monoculture cropping of soybean. In the opinion of Chen et al. (2008) and Leandro and Asmus (2015), lower yields in soybean monoculture can be attributed, among others, to damage caused by the soybean cyst nematode ( $\mathrm{SCN}$ ) (Heterodera glycines) and the reniform nematode (Rotylenchulus reniformis). Hamid et al. (2017), in turn, think that long-term soybean monoculture may contribute to suppression of SCN cysts through the assembly of bacterial and fungal communities in the rhizosphere. According to a study by Zhu et al. (2013), the number of Heterodera glycines eggs increased with the increasing number of years of soybean monoculture from 2 to 5 , whereas after 8 years of monoculture cropping a large decrease in the population of this pathogen was observed.

The seed yield of soybean grown after winter wheat was significantly positively correlated with plant density after emergence and before harvest, plant height and first pod height, seed weight per plant, and 1000 seed weight (Table 3). The regression correlation model shows that an increase by $1 \mathrm{~g}$ of seed weight per plant caused an average increase in seed yield by as much as about $0.2 \mathrm{t} \mathrm{ha}^{-1}$. An increase in the other characteristics by one unit contributed to an increase in yield from 0.02 to $0.1 \mathrm{t} \mathrm{ha}^{-1}$. All the yield components evaluated had a significantly positive effect on yield of monoculture-grown soybean. An increase in seed weight per plant by one unit resulted in an increase in yield by as much as $0.5 \mathrm{tha}^{-1}$. The value of the coefficient of determination $\left(\mathrm{R}^{2}\right)$ indicates that about $51 \%$ of the variance in yield was explained by the presented model.

Seeds of soybean grown in the stand after itself were characterized by a significantly higher percentage protein content and a lower fat content compared to these contents
Table 3 Straight correlation coefficients and simple regressions for the relationship between yield and soybean crop and yield components depending on cropping system

\begin{tabular}{lllll}
\hline Quality parametr & $\mathrm{r}_{\text {emp }}$ & Significance & $\mathrm{R}^{2}$ & Regression equation \\
\hline Crop rotation & & & & \\
Plant density after emergence & +0.76 & $* * *$ & 0.58 & $\mathrm{y}=0.6568+0.0272 \mathrm{x}$ \\
Plant density before harvest & +0.51 & $*$ & 0.26 & $\mathrm{y}=1.2397+0.0202 \mathrm{x}$ \\
Plant height & +0.78 & $* * *$ & 0.60 & $\mathrm{y}=0.6094+0.0388 \mathrm{x}$ \\
First pod height & +0.59 & $* *$ & 0.35 & $\mathrm{y}=1.577+0.1199 \mathrm{x}$ \\
Seed weight per plant & +0.50 & $*$ & 0.30 & $\mathrm{y}=1.3637+0.2221 \mathrm{x}$ \\
TSW & +0.83 & $* * *$ & 0.70 & $\mathrm{y}=-2.4452+0.0387 \mathrm{x}$ \\
Monoculture & & & & \\
Plant density after emergence & +0.70 & $* * *$ & 0.45 & $\mathrm{y}=0.1662+0.0383 \mathrm{x}$ \\
Plant density before harvest & +0.63 & $* * *$ & 0.40 & $\mathrm{y}=-0.8479+0.0612 \mathrm{x}$ \\
Plant height & +0.60 & $* *$ & 0.36 & $\mathrm{y}=0.8506+0.0292 \mathrm{x}$ \\
First pod height & +0.57 & $* *$ & 0.33 & $\mathrm{y}=1.4758+0.1366 \mathrm{x}$ \\
Number of pods per plant & +0.48 & $*$ & 0.23 & $\mathrm{y}=0.6779+0.0929 \mathrm{x}$ \\
Number of seeds per plant & +0.57 & $* *$ & 0.33 & $\mathrm{y}=-0.0608+0.0687 \mathrm{x}$ \\
Seed weight per plant & +0.72 & $* * *$ & 0.51 & $\mathrm{y}=0.004+0.506 \mathrm{x}$ \\
TSW & +0.80 & $* * *$ & 0.64 & $\mathrm{y}=-4.913+0.0572 \mathrm{x}$ \\
\hline
\end{tabular}

$r_{e m p}$ Pearson's correlation coefficient, $R^{2}$ coefficient of determination, TSW thousand seed weight

*Significance level at $\mathrm{p} \leq 0.05, * *$ significance level at $\mathrm{p} \leq 0.01, * * *$ significance level at $\mathrm{p} \leq 0.001$ 
found after the previous winter wheat crop, respectively by 2.2 and $1.0 \%$ (Tables 4 and 5).

Tillage system significantly modified soybean yield as well as percentage protein and fat content in seeds. Under plough tillage conditions (CT), the seed yield was higher by $10.3 \%$ compared to that obtained under no-tillage (NT) (Table 1). In the plough tillage treatment, plant density after emergence and before harvest, number of pods per plant, number and weight of seeds per plant, and thousand seed weight were also found to be significantly higher (Table 2). However, plough tillage adversely affected first pod height and soybean plant height (Table 2). Similar results were obtained in studies by Amini (2005), Barrios et al. (2006) and Monsefi et al. (2014) who found a significant decrease in yield under no-tillage conditions compared to conventional tillage. And conversely, Di Ciocco et al. (2008), Hosseini et al. (2016), and Moraru and Rusu (2012) recorded an increase in soybean yield under no-till conditions compared to conventional agronomy, whereas according to Karunakaran and Behera (2016) soybean under no-tillage showed similar productivity as conventional cropping. According to De Vita et al. (2007), the benefits arising from the use of no-till can be observed in warm years at lower rainfall. This was most probably associated with higher water accumulation in the soil caused by lower evaporation and changes in soil water permeability under no-tillage conditions (Martinez et al. 2008). More stable thermal conditions in the $0-15 \mathrm{~cm}$ soil layer and an average increase in its temperature by $0.5-2.2{ }^{\circ} \mathrm{C}$ may also contribute to higher soybean yields under NT relative to CT (Moraru and Rusu 2012).

The 4-year study revealed that no-tillage increases first pod height and soybean plant height (Table 2). Bujak et al. (2001) also proved a tendency towards lengthening of soybean stems and increased first pod height under reduced tillage conditions. Nevertheless, the study by Monsefi et al. (2014) showed tillage system to have a significant impact on soybean plant height only during the initial period of growth, whereas the plant height before harvest was similar in the case of both no-tillage and conventional tillage.

Plough tillage was proven to have a positive effect on plant density after emergence in the case of soybean cropping in crop rotation. The statistical analysis did not show the interaction of the experimental factors to affect the other soybean yield and crop characteristics (Table 6).

The dependence of soybean seed yield on yield components varied for the tillage systems studied (Table 7). Under plough tillage system, it was shown that with an increase in plant height, number of pods per plant, number and weight of seeds per plant, and 1000 seed weight by one unit, the yield increased on average from 0.03 to $0.08 \mathrm{t} \mathrm{ha}^{-1}$. Under
Table 4 Protein content in soybean seeds (\%) depending on cropping system and tillage system throughout the study period

\begin{tabular}{|c|c|c|c|c|c|c|c|c|c|}
\hline \multirow[t]{2}{*}{ Year } & \multicolumn{3}{|c|}{ Crop rotation } & \multicolumn{3}{|c|}{ Monoculture } & \multicolumn{2}{|c|}{ Mean } & \multirow[t]{2}{*}{ Mean } \\
\hline & $\mathrm{CT}$ & NT & Mean & $\mathrm{CT}$ & NT & Mean & $\mathrm{CT}$ & NT & \\
\hline 2014 & 32.6 & 33.3 & 33.0 & 36.0 & 37.5 & 36.8 & 34.3 & 35.4 & 34.9 \\
\hline 2015 & 31.1 & 32.0 & 31.6 & 37.3 & 37.9 & 37.6 & 34.2 & 34.9 & 34.6 \\
\hline 2016 & 35.1 & 34.8 & 35.0 & 35.1 & 35.3 & 35.2 & 35.1 & 35.1 & 35.1 \\
\hline 2017 & 33.1 & 33.1 & 33.1 & 32.0 & 32.1 & 32.0 & 32.6 & 32.6 & 32.6 \\
\hline Mean & 33.0 & 33.3 & 33.2 & 35.1 & 35.7 & 35.4 & 34.0 & 34.5 & - \\
\hline $\mathrm{LSD}_{0.05}$ & \multicolumn{9}{|c|}{$\begin{array}{l}\text { Cropping system }-0.40 \text {, tillage system }-0.40 \text {, years }-0.75 \text {, cropping system } \times \text { tillage } \\
\text { system }- \text { ns, cropping system } \times \text { years }-1.26 \text {, tillage system } \times \text { years }-n s \text {, cropping sys- } \\
\text { tem } \times \text { tillage system } \times \text { vears }-n s\end{array}$} \\
\hline
\end{tabular}

$n s$ not significant at $\mathrm{p} \leq 0.05, C T$ plough tillage, $N T$ no-tillage

\begin{tabular}{|c|c|c|c|c|c|c|c|c|c|}
\hline \multirow[t]{2}{*}{ Year } & \multicolumn{3}{|c|}{ Crop rotation } & \multicolumn{3}{|c|}{ Monoculture } & \multicolumn{2}{|c|}{ Mean } & \multirow[t]{2}{*}{ Mean } \\
\hline & CT & NT & Mean & $\mathrm{CT}$ & NT & Mean & $\mathrm{CT}$ & NT & \\
\hline 2014 & 19.6 & 19.3 & 19.4 & 17.7 & 16.8 & 17.2 & 18.6 & 18.0 & 18.3 \\
\hline 2015 & 21.0 & 20.6 & 20.8 & 17.9 & 17.2 & 17.6 & 19.4 & 18.9 & 19.2 \\
\hline 2016 & 18.7 & 18.8 & 18.8 & 18.0 & 18.0 & 18.0 & 18.4 & 18.4 & 18.4 \\
\hline 2017 & 18.0 & 17.1 & 17.6 & 20.4 & 20.1 & 20.2 & 19.2 & 18.6 & 18.9 \\
\hline Mean & 19.3 & 19.0 & 19.2 & 18.5 & 18.0 & 18.2 & 18.9 & 18.5 & - \\
\hline $\mathrm{LSD}_{0.05}$ & \multicolumn{9}{|c|}{$\begin{array}{l}\text { Cropping system }-0.18 \text {, tillage system }-0.18 \text {, years }-0.33 \text {, cropping system } \times \text { tillage } \\
\text { system }- \text { ns, cropping system } \times \text { years }-0.56 \text {, tillage system } \times \text { years }-0.56, \text { cropping sys- } \\
\text { tem } \times \text { tillage system } \times \text { years }-\mathrm{ns}\end{array}$} \\
\hline
\end{tabular}

$n s$ not significant at $\mathrm{p} \leq 0.05, C T$ plough tillage, $N T$ no-tillage 
Table 6 Effect of interaction relationships between cropping system and tillage system on soybean crop and yield components (on average for 2014-2017)

\begin{tabular}{|c|c|c|c|c|c|}
\hline \multirow[t]{2}{*}{ Specification } & \multicolumn{2}{|c|}{ Crop rotation } & \multicolumn{2}{|c|}{ Monoculture } & \multirow[t]{2}{*}{$\mathrm{LSD}_{0.05}$} \\
\hline & $\mathrm{CR}$ & $\mathrm{CM}$ & $\mathrm{CT}$ & NT & \\
\hline Plant density after emergence (plants $\mathrm{m}^{-2}$ ) & 67.2 & 59.2 & 60.7 & 60.8 & $\mathrm{CS} \times \mathrm{TS}-6.71$ \\
\hline Plant density before harvest (plants $\mathrm{m}^{-2}$ ) & 60.3 & 52.3 & 55.8 & 53.4 & $\mathrm{CS} \times \mathrm{TS}-\mathrm{ns}$ \\
\hline Plant height $(\mathrm{cm})$ & 44.8 & 46.5 & 54.9 & 57.6 & $\mathrm{CS} \times \mathrm{TS}-\mathrm{ns}$ \\
\hline First pod height $(\mathrm{cm})$ & 6.2 & 7.2 & 6.8 & 8.1 & $\mathrm{CS} \times \mathrm{TS}-\mathrm{ns}$ \\
\hline Number of pods per plant (pcs.) & 18.2 & 16.3 & 20.9 & 18.2 & $\mathrm{CS} \times \mathrm{TS}-\mathrm{ns}$ \\
\hline Number of seeds per plant (pcs.) & 37.1 & 34.4 & 39.4 & 35.0 & $\mathrm{CS} \times \mathrm{TS}-\mathrm{ns}$ \\
\hline Seed weight per plant $(\mathrm{g})$ & 4.71 & 4.42 & 5.09 & 4.75 & $\mathrm{CS} \times \mathrm{TS}-\mathrm{ns}$ \\
\hline TSW (g) & 125.5 & 123.7 & 130.2 & 128.7 & $\mathrm{CS} \times \mathrm{TS}-\mathrm{ns}$ \\
\hline
\end{tabular}

$n s$ not significant at $\mathrm{p} \leq 0.05, C S$ cropping system, $C R$ crop rotation, $C M$ monoculture, $T S$ tillage system, $C T$ plough tillage, $N T$ no-tillage, $T S W$ thousand seed weight

\begin{tabular}{lllll}
\hline Quality parametr & $\mathrm{r}_{\mathrm{emp}}$ & Significance & $\mathrm{R}^{2}$ & Regression equation \\
\hline Plough tillage & & & & \\
TSW & +0.84 & $* * *$ & 0.71 & $\mathrm{y}=-3.1608+0.0447 \mathrm{x}$ \\
Plant height & +0.61 & $* *$ & 0.37 & $\mathrm{y}=0.9089+0.0331 \mathrm{x}$ \\
Number of pods & +0.55 & $*$ & 0.30 & $\mathrm{y}=0.922+0.0838 \mathrm{x}$ \\
Number of seeds per plant & +0.53 & $*$ & 0.29 & $\mathrm{y}=0.8744+0.044 \mathrm{x}$ \\
Seed weight per plant & +0.63 & $*$ & 0.40 & $\mathrm{y}=1.0413+0.3094 \mathrm{x}$ \\
No-tillage & & & & \\
Plant density after emergence & +0.87 & $* * *$ & 0.75 & $\mathrm{y}=0.0374+0.038 \mathrm{x}$ \\
Plant density before harvest & +0.78 & $* * *$ & 0.60 & $\mathrm{y}=-0.3217+0.0499 \mathrm{x}$ \\
Plant height & +0.78 & $* * *$ & 0.60 & $\mathrm{y}=-0.3217+0.0499 \mathrm{x}$ \\
Seed weight per plant & +0.56 & $*$ & 0.31 & $\mathrm{y}=0.6006+0.3736 \mathrm{x}$ \\
TSW & +0.75 & $* *$ & 0.57 & $\mathrm{y}=-3.3495+0.0449 \mathrm{x}$ \\
\hline
\end{tabular}

$r_{\text {emp }}$ Pearson's correlation coefficient, $R^{2}$ coefficient of determination, TSW thousand seed weight

*Significance level at $\mathrm{p} \leq 0.05$, **significance level at $\mathrm{p} \leq 0.01, * * *$ significance level at $\mathrm{p} \leq 0.001$ no-tillage system, soybean yield was significantly influenced by plant density, both after emergence and before harvest, plant height, seed weight per plant, and TSW. The linear regression correlation model reveals that an increase by $1 \mathrm{~g} \mathrm{~m}^{-2}$ of seed weight per plant resulted in an average increase in seed yield by about $0.3 \mathrm{t} \mathrm{ha}^{-1}$. Nonetheless, the coefficient of determination $\left(\mathrm{R}^{2}\right)$ indicates that only $31 \%$ of the variance in yield was explained by the presented model.

Soil nutrient distribution is affected by soil tillage, that is, soil tilling operations carried out at different depths, overturning the soil or mixing it, or the abandonment of tillage (no-tillage) (Angers et al. 2008; Du et al. 2017; Woźniak 2019). A study by Lüder et al. (2019) confirmed that already three-year no-tillage in a field results in a distinct stratification of elements in the soil profile. More $\mathrm{N}$ was recorded in the $0-15 \mathrm{~cm}$ layer under NT than under CT. Opposite relationships were found in the deeper soil layer $-15-30 \mathrm{~cm}$. The distribution of nutrients in soil affects their uptake and plant chemical composition (Lüder et al. 2019; Virk et al. 2019). In the present study, under no-tillage conditions a higher seed protein content and a lower fat content were found compared to plough tillage, respectively by 0.5 and $0.4 \%$ (Tables 4 and 5). The results of other authors' research are not unequivocal. Lüder et al. (2019) showed winter wheat grain to be less protein-rich under NT in comparison to CT, while according to Woźniak and Soroka (2014) triticale grain contained more protein under NT conditions than under CT. Gao et al. (2009), however, obtained an increase in fat yield per hectare for non-tilled soybean.

The interaction of the experimental factors was not proven to affect soybean yields and the studied seed quality characteristics (Tables 1, 4 and 5). On the other hand, a study by Morrison et al. (2018) demonstrates that soybean seed yield did not differ between crop rotation and monoculture, regardless whether CT or NT was used. Nonetheless, under conventional tillage conditions wheat and maize produced higher yields by $22 \%$ and $8 \%$, respectively, than in monoculture. 


\section{Economic Evaluation of Soybean Cropping}

An important aspect of this study was to perform an economic evaluation of soybean production effects depending on cropping system and the type of previous crop. The amount of income earned by farmers depends on the level of yield and selling price (Boczar 2016). The data collated in Table 8 show that the highest value of output per hectare of soybean on average for the period 2014-2017 was obtained in the case of tillage system combined with monoculture (EUR 909.9). The fluctuations in yield and market prices of soybeans caused the value of output to vary between years. In all cultivation treatments, the highest output was recorded in 2016, which was an effect of both high yields and relatively high selling prices of soybeans.

The gross margin value indicated that soybean cropping using plough tillage system is justified (Table 9). On average over the study period, it was higher by EUR 82.9 per ha and
EUR 76.6 per ha than soybean cropping under no-tillage system for, respectively, crop rotation and monoculture. In analyzing both tillage systems, regardless of the previous crop, it can be stated that the average difference in gross margin between these two systems for the period 2014-2017 was EUR 79.8 per ha in favor of plough tillage system.

Operating income, which is calculated as the difference between output and total costs, is an important economic category in evaluation of production profitability. Due to the fact that farmers can obtain direct payments to production, this category was calculated including direct payments and without them (Table 9). Where direct payments were not included in income, in the 2 years studied (2015 and 2017) income was negative in each cultivation treatment. In the other two years, a predominance of plough tillage over no-tillage could be seen in terms of profitability. After including direct payments to production, operating income reached a positive value in each cultivation system analyzed.
Table 8 Output per ha of soybean (EUR per ha)

Table 9 Gross margin and operating income per ha of soybean in 2014-2017 (in EUR)

\begin{tabular}{|c|c|c|c|c|c|c|c|c|c|}
\hline \multirow[t]{2}{*}{ Year } & \multicolumn{3}{|c|}{ Crop rotation } & \multicolumn{3}{|c|}{ Monoculture } & \multicolumn{3}{|l|}{ Mean } \\
\hline & $\mathrm{CT}$ & NT & Mean & $\mathrm{CT}$ & NT & Mean & $\mathrm{CT}$ & NT & Mean \\
\hline 2014 & 956.1 & 1006.3 & 981.2 & 1052.5 & 1021.7 & 1037.1 & 1004.3 & 1014.0 & 1009.2 \\
\hline 2015 & 703.9 & 610.1 & 657.0 & 747.5 & 623.5 & 685.5 & 725.7 & 616.8 & 671.3 \\
\hline 2016 & 1077.5 & 989.4 & 1033.5 & 1264.1 & 1137.3 & 1200.7 & 1170.8 & 1063.4 & 1117.1 \\
\hline 2017 & 738.5 & 538.5 & 638.5 & 575.4 & 550.8 & 563.1 & 656.9 & 544.6 & 600.8 \\
\hline Mean & 869.0 & 786.1 & - & 909.9 & 833.3 & - & 833.3 & 833.3 & - \\
\hline
\end{tabular}

$C T$ plough tillage, $N T$ no-tillage

\begin{tabular}{|c|c|c|c|c|c|c|c|c|c|}
\hline \multirow[t]{2}{*}{ Year } & \multicolumn{3}{|c|}{ Crop rotation } & \multicolumn{3}{|c|}{ Monoculture } & \multicolumn{3}{|l|}{ Mean } \\
\hline & CT & NT & Mean & $\mathrm{CT}$ & NT & Mean & $\mathrm{CT}$ & NT & Mean \\
\hline \multicolumn{10}{|c|}{ Gross margin (EUR per ha) } \\
\hline 2014 & 420.0 & 470.1 & 445.1 & 516.4 & 485.5 & 501.0 & 468.2 & 477.8 & 473.0 \\
\hline 2015 & 181.6 & 87.8 & 134.7 & 225.2 & 101.2 & 163.2 & 203.4 & 94.5 & 149.0 \\
\hline 2016 & 555.2 & 467.1 & 511.2 & 741.8 & 615.0 & 678.4 & 648.5 & 541.1 & 594.8 \\
\hline 2017 & 235.1 & 35.1 & 135.1 & 72.0 & 47.4 & 59.7 & 153.5 & 41.2 & 97.4 \\
\hline Mean & 348.0 & 265.0 & - & 388.8 & 312.3 & - & 368.4 & 288.7 & - \\
\hline \multicolumn{10}{|c|}{ Operating income without direct payments (EUR per ha) } \\
\hline 2014 & 153.4 & 219.2 & 186.3 & 249.8 & 234.6 & 242.2 & 201.6 & 226.9 & 214.3 \\
\hline 2015 & -78.0 & -156.7 & -117.4 & -34.5 & -143.3 & -88.9 & -56.3 & -150.0 & -103.1 \\
\hline 2016 & 295.5 & 222.7 & 259.1 & 482.1 & 370.6 & 426.3 & 388.8 & 296.6 & 342.7 \\
\hline 2017 & -15.2 & -200.5 & -107.9 & -178.3 & -188.2 & -183.3 & -96.8 & -194.4 & -145.6 \\
\hline Mean & 88.9 & 21.2 & - & 129.8 & 68.4 & - & 109.3 & 44.8 & - \\
\hline \multicolumn{10}{|c|}{ Operating income with direct payments (EUR per ha) } \\
\hline 2014 & 511.5 & 577.3 & 544.4 & 607.9 & 592.7 & 600.3 & 559.7 & 585.0 & 572.3 \\
\hline 2015 & 229.5 & 150.8 & 190.2 & 273.0 & 164.2 & 218.6 & 251.3 & 157.5 & 204.4 \\
\hline 2016 & 603.8 & 531.0 & 567.4 & 790.5 & 678.9 & 734.7 & 697.1 & 605.0 & 651.1 \\
\hline 2017 & 330.0 & 144.6 & 237.3 & 166.9 & 157.0 & 161.9 & 248.4 & 150.8 & 199.6 \\
\hline Mean & 418.7 & 350.9 & - & 459.6 & 398.2 & - & 439.1 & 374.6 & - \\
\hline
\end{tabular}

$C T$ plough tillage, $N T$ no-tillage 
Over the period studied, the average income per hectare of soybean under plough tillage system was EUR 439.1 per ha and it was higher by EUR 64.6 than that under no-tillage. It can also be noticed that from the economic point of view it was beneficial to grow soybean in monoculture. In monoculture, both plough tillage and no-tillage generated a higher income per ha of soybean than where soybean was grown in crop rotation (except for the year 2017). Apart from income derived directly from grain production, the profitability of soybean cultivation is also impacted by additional economic benefits in the form of nitrogen fixed by nodule bacteria, improved soil structure, and increased yields of succeeding crops. However, these benefits relate to each of the treatments analyzed.

Information on production costs can help farmers in making efficient and effective decisions (Artuzo et al. 2018). When analyzing production costs per 1 tonne of soybeans, it can be noted that they differed both between years and depending on cultivation system (Table 10). The average level of costs per one tonne of soybeans during the period 2014-2017 was EUR 317 in the case of plough tillage, whereas for no-tillage it was EUR 355.3. A study conducted by Boczar (2016) based on the Cash Crop (2015) demonstrates that farms from Argentina had the lowest soybean production costs (EUR 120-140 per tonne) among the countries analyzed in this report, followed by Brazil (EUR 220-240 per tonne). In the case of Polish farms, the average soybean production cost over the period 2012-2014 was EUR 324 per tonne.

\section{Conclusions}

The present study investigated the effect of cropping system and tillage system on yield and some quality characteristics of soybeans. It also evaluated the economic effects of the soybean production technologies studied. Therefore, this paper, which covers technological, quality, and economic aspects, is of interdisciplinary nature. Most of the available studies are focused only on the production of high soybean yields and neglect the importance of economic effectiveness. But under market economy conditions, decisions related to the selection of the production structures and cultivation method are made not only based on the production and quality characteristics, but also on the basis of economic results. On average over the four-year study period, the soybean seed yield was significantly higher in monocultural stands compared to the yield obtained under crop rotation (by 5.0\%). A decreasing trend in monocultured soybean was only observed in the 4th year of the experiment. The correlation analysis proved that all the yield components evaluated had a significant positive effect on yield of monoculture-grown soybean, while an increase in seed weight per plant by one unit caused an increase in yield by as much as $0.5 \mathrm{tha}^{-1}$. Seeds of soybean grown in the stand after itself were also characterized by a significantly higher percentage protein content and a lower fat content compared to those obtained in crop rotation. In the plough tillage treatment, the seed yield was higher by $10.3 \%$ compared to that obtained under notillage. The correlation analysis showed that under plough tillage system with an increase in plant height, number of pods per plant, number and weight of seeds per plant, and 1000 seed weight by one unit, the yield increased on average from 0.03 to $0.08 \mathrm{t} \mathrm{ha}^{-1}$. Under no-tillage conditions, a higher seed protein content and a lower fat content were found. The highest average output per ha during the period 2014-2017 was obtained for soybean grown in monoculture under plough tillage. The average income per ha of soybean grown under plough tillage system was higher by EUR 64.6 than that under no-tillage. From the economic point of view, it was more beneficial to grow soybean in monoculture. In monoculture, both plough tillage and notillage generated a higher income per ha than where soybean was grown in crop rotation (except for the year 2017).

The current climate change obliges scientists to conduct continuous research on the optimization of soybean cultivation. Experiments should focus on the development of technologies that are both environmentally friendly and economically profitable. Especially great attention should be devoted to no-tillage which promotes soil water accumulation and allows satisfactory soybean yields to be obtained in a growing season characterized by a rainfall deficit.
Table 10 Total costs per tonne of soybeans depending on cultivation system (EUR per tonne)

\begin{tabular}{|c|c|c|c|c|c|c|c|c|c|}
\hline \multirow[t]{2}{*}{ Year } & \multicolumn{3}{|c|}{ Crop rotation } & \multicolumn{3}{|c|}{ Monoculture } & \multicolumn{3}{|l|}{ Mean } \\
\hline & CT & NT & Mean & CT & NT & Mean & CT & NT & Mean \\
\hline 2014 & 314.6 & 298.9 & 306.7 & 285.8 & 294.4 & 290.1 & 300.2 & 296.7 & 298.4 \\
\hline 2015 & 371.5 & 428.7 & 400.1 & 349.8 & 419.4 & 384.6 & 360.7 & 424.1 & 392.4 \\
\hline 2016 & 255.0 & 277.6 & 266.3 & 217.3 & 241.5 & 229.4 & 236.1 & 259.6 & 247.9 \\
\hline 2017 & 325.1 & 445.8 & 385.4 & 417.2 & 435.8 & 426.5 & 371.1 & 440.8 & 406.0 \\
\hline Mean & 316.5 & 362.8 & - & 317.5 & 347.8 & - & 317.0 & 355.3 & - \\
\hline
\end{tabular}

$C T$ plough tillage, $N T$ no-tillage 
Funding Research financed by the Ministry of Science and Higher Education of Poland as the part of statutory activities of Department of Herbology and Plant Cultivation Techniques, University of Life Sciences in Lublin.

\section{Compliance with Ethical Standards}

Conflict of Interest The authors declare that they have no conflict of interest.

Open Access This article is licensed under a Creative Commons Attribution 4.0 International License, which permits use, sharing, adaptation, distribution and reproduction in any medium or format, as long as you give appropriate credit to the original author(s) and the source, provide a link to the Creative Commons licence, and indicate if changes were made. The images or other third party material in this article are included in the article's Creative Commons licence, unless indicated otherwise in a credit line to the material. If material is not included in the article's Creative Commons licence and your intended use is not permitted by statutory regulation or exceeds the permitted use, you will need to obtain permission directly from the copyright holder. To view a copy of this licence, visit http://creativecommons.org/licenses/by/4.0/.

\section{References}

Abbasi Surki, A., Sharifzade, F., Tavakkol Afshari, R., Majnoun Hosseini, N., \& Gazor, H. R. (2010). Optimization of processing parameters of soybean seeds dried in a constant-bed dryer using response surface methodology. Journal of Agricultural Science and Technology, 12, 409-423.

Amini, I. (2005). Determination of the best management for soybean cropping following barley. Soil and Tillage Research. https://doi. org/10.1016/j.still.2004.11.002.

Angers, D. A., \& Eriksen-Hamel, N. S. (2008). Full-inversion tillage and organic carbon distribution in soil profiles: A meta-analysis. Soil Science Society of America Journal. https://doi.org/10.2136/sssaj2007.0342.

Artuzo, F. D., Foguesatto, C. R., De Souza, A. R. L., \& Da Silva, L. $X$. (2018). Costs management in maize and soybean production. Review of Business Management. https://doi.org/10.7819/rbgn. v20i2.3192.

Barrios, M. B., Bozzo, A. A., Debelis, S. P., Pereyra, A. M., \& Bujan, A. (2006). Soil physical properties and root activity in a soybean second crop/maize rotation under direct sowing and conventional tillage. Spanish Journal of Agricultural Research. https://doi. org/10.5424/sjar/2006044-212.

BBCH Working Group. (2001). Growth stages of mono-and dicotyledonous plants. In U. Meier (Ed.), Federal biological research centre for agriculture and forestry (2nd ed). Berlin, Germany; Braunschweig, Germany.

Bellaloui, N., Bruns, H. A., Gillen, A. M., Abbas, H. K., Zablotowicz, R. M., Mengistu, A., et al. (2010). Soybean seed protein, oil, fatty acid and mineral composition as influence by soybeancorn rotation. Agricultural Sciences. https://doi.org/10.4236/ as.2010.13013.

Bieniaszewski, T., Szwejkowski, Z., \& Fordoński, G. (2000). Impact of temperature and rainfall distribution over 1989-1996 on the biometric and structural characteristics as well as on the 'Juno' yellow lupin yielding. Electronic Journal of Polish Agricultural Universities, Series Agronomy, https://www.ejpau.media.pl/serie s/volume3/issue2/agronomy/art-02.html. Accessed 15 Mar 2019.

Boczar, P. (2016). The economic importance of soybean and possibility of expanding its production in Poland. Problems of
World Agriculture/Problemy Rolnictwa Światowego. https://doi. org/10.22004/ag.econ.250164.

Boros, L. (2002). Soja — charakterystyka odmian i technologia uprawy. IHAR, Radzików, 18 (In Polish).

Bujak, K., Jędruszczak, M., \& Frant, M. (2004). The effect of reduced tillage and foliar nutrition by macro- and microelements on the yielding of soybean growing in monoculture. Annales Universitatis Mariae Curie-Sktodowska, Sectio E, 59(1), 139-147. (In Polish).

Bujak, K., Jędruszczak, M., \& Frant, M. (2001). The influence of reduced tillage methods on soybean seed yield. Biuletyn IHAR, 220, 263-272. (In Polish).

Cash Crop Report (2015). Key results of the 2014 agri benchmark farm comparison. https://www.agribenchmark.org/cash_crop. html. Accessed 06 Mar 2019.

Chen, S., Johnson, G., Warnke, S., Wyse, D., \& Porter, P. (2008). Effect of rotation crops on hatch, viability and development of Heterodera glycines. Nematology. https://doi.org/10.1163/15685 4108786161391.

Cox, W. J., Hanchar, J. J., \& Cherney, J. (2018). Agronomic and economic performance of maize, soybean, and wheat in different rotations during the transition to an organic cropping system. Agronomy-Basel. https://doi.org/10.3390/agronomy8090192.

De Vita, P., Di Paolo, E., Fecondo, G., Di Fonzo, N., \& Pisante, M. (2007). No-tillage and conventional tillage effects on durum wheat yield, grain quality and soil moisture content in southern Italy. Soil and Tillage Research. https://doi.org/10.1016/j.still .2006.01.012.

Derpsch, R., Friedrich, T., Kassam, A., \& Hongwen, L. (2010). Current status of adoption of no-till farming in the world and some of its main benefits. International Journal of Agricultural and Biological Engineering. https://doi.org/10.3965/j. issn.1934-6344.2010.01.0-0.

Di Ciocco, C., Coviella, C., Penon, E., Diaz-Zorita, M., \& Lopez, S. (2008). Short communication. Biological fixation of nitrogen and $\mathrm{N}$ balance in soybean crops in the pampas region. Spanish Journal of Agricultural Research. https://doi.org/10.5424/sjar/20080 61-5259.

Du, Z., Angers, D. A., Ren, T., Zhang, Q., \& Li, G. (2017). The effect of no-till on organic $\mathrm{C}$ storage in Chinese soils should not be overemphasized: A meta-analysis. Agriculture, Ecosystems and Environment,. https://doi.org/10.1016/j.agee.2016.11.007.

Erenstein, O., Sayre, K., Wall, P., Hellin, J., \& Dixon, J. (2012). Conservation Agriculture in maize- and wheat-based systems in the (sub)tropics: lessons from adaptation initiatives in South Asia, Mexico, and Southern Africa. Journal of Sustainable Agriculture. https://doi.org/10.1080/10440046.2011.620230.

European Commission. (2018). Report from the Commission to the Council and the European Parliament on the development of plant proteins in the European Union, Brussels, 22.11.2018 COM(2018) 757 final.

Gao, J., Hao, X., Thelen, K. D., \& Robertson, G. P. (2009). Agronomic management system and precipitation effects on soybean oil and fatty acid profiles. Crop Science. https://doi.org/10.2135/crops ci2008.08.0497.

Goraj, L., \& Mańko, S. (2009). Rachunkowość i analiza ekonomiczna $w$ indywidualnym gospodarstwie rolnym. Warszawa: Difin. (In Polish).

Hamid, M. I., Hussain, M., Wu, Y., Zhang, X., Xiang, M., \& Liu, X. (2017). Successive soybean-monoculture cropping assembles rhizosphere microbial communities for the soil suppression of soybean cyst nematode. FEMS Microbiology Ecology. https://doi. org/10.1093/femsec/fiw222.

Hobbs, P. R., Sayre, K., \& Gupta, R. (2008). The role of conservation agriculture in sustainable agriculture. Philosophical Transactions of Royal Society B. https://doi.org/10.1098/rstb.2007.2169. 
Hosseini, S. Z., Firouzi, S., Aminpanah, H., \& Sadeghnejhad, H. R. (2016). Effect of tillage system on yield and weed populations of soybean (Glycin max L.). Anais da Academia Brasileira de Ciencias. https://doi.org/10.1590/0001-3765201620140590.

IUSS Working Group WRB. (2015). World Reference Base for Soil Resources 2014, update 2015. International soil classification system for naming soils and creating legends for soil maps. In: World Soil Resources Reports No. 106. FAO, Rome.

Karunakaran, V., \& Behera, U. K. (2016). Tillage and residue management for improving productivity and resource use efficiency in soybean (Glycine max) —wheat (Triticum aestivum) cropping system. Experimental Agriculture. https://doi.org/10.1017/S0014 479715000289.

Kelley, K. W., Long, J. H., \& Todd, T. C. (2003). Long-term crop rotations affect soybean yield, seed weight, and soil chemical properties. Field Crops Research. https://doi.org/10.1016/S0378 $-4290(03) 00055-8$.

Kołodziej, J., \& Pisulewska, E. (2000). Effect of climatic factors on seed yield, fat yield and fat content in seeds of two soybean cultivars. Rośliny Oleiste Oilseed Crops, 21(3), 759-776. (In Polish).

Leandro, H. M., \& Asmus, G. L. (2015). Crop rotation and crop sequences for the management of the reniform nematode in area of soybean production. Ciência Rural. https://doi.org/10.1590/01038478cr20130526. (Accessed 10 Feb 2020).

Lüder, R. M. H., Qin, R. J., Richner, W., Stamp, P., Streit, B., \& Noulas, C. (2019). Effect of tillage systems on spatial variation in soil chemical properties and winter wheat (Triticum aestivum L.) performance in small fields. Agronomy-Basel. https://doi. org/10.3390/agronomy9040182.

Martinez, E., Fuentes, J., Silva, P., Valle, S., \& Acevedo, E. (2008). Soil physical properties and wheat root growth as affected by no-tillage and conventional tillage systems in a Mediterranean environment of Chile. Soil and Tillage Research. https://doi.org/10.1016/j.still .2008.02.001.

Monsefi, A., Sharma, A. R., Rang Zan, N., Behera, U. K., \& Das, T. K. (2014). Effect of tillage and residue management on productivity of soybean and physic-chemical properties of soil in soybeanwheat cropping system. International Journal of Plant Production. https://doi.org/10.22069/ijpp.2014.1618.

Moraru, P. I., \& Rusu, T. (2012). Effect of tillage systems on soil moisture, soil temperature, soil respiration and production of wheat, maize and soybean crops. Journal of Food, Agriculture and Environment, 10(2), 445-448.

Morrison, M. J., Cober, E. R., Gregorich, E. G., Voldeng, H. D., Ma, B., \& Topp, G. C. (2018). Tillage and crop rotation effects on the yield of corn, soybean, and wheat in eastern Canada. Canadian Journal of Plant Science. https://doi.org/10.1139/cjps-2016-0407.

Nowak, A. (2011). Nasiona soi zwyczajnej-cenny surowiec dietetyczny i leczniczy. Kosmos, 60(1-2), 179-187. (In Polish).

Ohnishi, S., Miyoshi, T., \& Shirai, S. (2010). Low temperature stress at different flower developmental stages affects pollen development, pollination, and pod set in soybean. Environmental and Experimental Botany. https://doi.org/10.1016/j.envexpbot.2010.02.007.

Pittelkow, C. M., Linquist, B. A., Lundy, M. E., Liang, X., Van Groenigen, K. J., Lee, J., et al. (2015). When does no-till yield more? A global meta-analysis. Field Crops Research. https://doi. org/10.1016/j.fcr.2015.07.020.

Plourde, J. D., Pijanowski, B. C., \& Pekin, B. K. (2013). Evidence for increased monoculture cropping in the Central United States. Agriculture, Ecosystems and Environment, https://doi. org/10.1016/j.agee.2012.11.011.
Praczyk, T., Nawracała, J., Balcer, G., Bubniewicz, P., \& Filoda, G. (2012). Metodyka integrowanej ochrony soi dla producentów. Poznań: Instytut Ochrony Roślin Państwowy Instytut Badawczy. (In Polish).

Reckling, M., Döring, T. F., Bergkvist, G., Stoddard, F. L., Watson, C. A., Seddig, S., et al. (2018). Grain legume yields are as stable as other spring crops in long-term experiments across northern Europe. Agronomy for Sustainable Development. https://doi. org/10.1007/s13593-018-0541-3.

Rogalska-Niedźwiedź, M. (2000). Białko sojowe. Debata, 2(2), $121-$ 132. (In Polish).

Santos, H. P., Fontaneli, R. S., Pires, J., Lampert, E. A., Vargas, A. M., \& Verdi, A. C. (2014). Grain yield and agronomic traits in soybean according to crop rotation systems. Bragantia. https:// doi.org/10.1590/1678-4499.0136.

Skarżyńska, A., Abramczuk, Ł., \& Jabłoński, K. (2016). Impact of growing costs on the profitability of crop production in Poland in the mid-term perspective. Journal of Central European Agriculture. https://doi.org/10.5513/JCEA01/17.1.1680.

Thuzar, M., Puteh, A. B., Abdullah, N. A. P., Lassim, M. B. M., \& Jusoff, K. (2010). The effects of temperature stress on the quality and yield of soya bean [(Glycine $\max$ L.) Merrill.]. Journal of Agricultural Science. https://doi.org/10.5539/jas.v2n1p172.

Woźniak, A. (2019). Chemical properties and enzyme activity of soil as affected by tillage system and previous crop. Agriculture. https ://doi.org/10.3390/agriculture9120262.

Woźniak, A., \& Soroka, A. (2014). Effects of a 3-year reduced tillage on the yield and quality of grain and weed infestation of spring triticale (Triticosecale Wittmack). International Journal of Plant Production. https://doi.org/10.22069/ijpp.2014.1526.

Vadez, V., Berger, J. D., Warkentin, T., Asseng, S., Ratnakumar, P., Rao, K. P. C., et al. (2011). Adaptation of grain legumes to climate change: a review. Agronomy for Sustainable Development. https:// doi.org/10.1007/s13593-011-0020-6.

Verhulst, N., Govaerts, B., Verachtert, E., Castellanos-Navarrete, A., Mezzalama, M., Wall, P. C., et al. (2010). Conservation agriculture, improving soil quality for sustainable production systems? In R. Lal \& B. A. Stewart (Eds.), Advances in soil science: food security and soil quality (pp. 137-208). Boca Raton: CRC Press.

Vincent-Caboud, L., Vereecke, L., Silva, E., \& Peigne, J. (2019). Cover crop effectiveness varies in cover crop-based rotational tillage organic soybean systems depending on species and environment. Agronomy-Basel. https://doi.org/10.3390/agronomy9060319.

Virk, H. K., Singh, G., \& Manes, G. S. (2019). Nutrient uptake, nitrogen use efficiencies, and energy indices in soybean under various tillage systems with crop residue and nitrogen levels after combine harvested wheat. Journal of Plant Nutrition. https://doi. org/10.1080/01904167.2019.1683190.

Vollmann, J., Winkler, J., Fritz, C. N., Grausgruber, H., \& Ruckenbauer, P. (2000). Spatial field variations in soybean (Glycine max [L.] Merr.) performance trials affect agronomic characters and seed composition. European Journal of Agronomy. https://doi. org/10.1016/S1161-0301(99)00042-8.

Zeller, F. J. (1999). Die Sojabohne (Glycine max (L.) Merr.): Nutzung, Genetik, Biotechnologie. . Die Bodenkultur, 50(3), 191-202.

Zhu, Y., Shi, F., Tian, J., Liu, J., Chen, S., Xiang, M., et al. (2013). Effect of soybean monoculture on the bacterial communities associated with cysts of Heterodera glycines. Journal of Nematology, 45(3), 228-235. 